\title{
Viral load estimation in asymptomatic honey bee colonies using the quantitative RT-PCR technique*
}

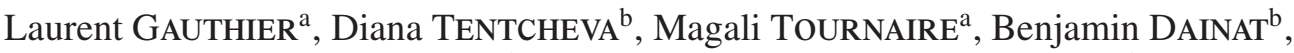 \\ François Cousserans ${ }^{\mathrm{b}}$, Marc Edouard COLIN $^{\mathrm{a}}$, Max BERGOIN $^{\mathrm{b}}$ \\ ${ }^{a}$ Laboratoire de Pathovigilance et de Développement Apicole, Montpellier SupAgro, 900 rue Jean François \\ Breton, 34090 Montpellier, France \\ ${ }^{\mathrm{b}}$ Laboratoire de Biologie Intégrative et Virologie des Insectes, UMR 1231, Université Montpellier II, place \\ Bataillon, 34095 Montpellier, France
}

Received 29 January 2007 - Accepted 4 May 2007

\begin{abstract}
Honey bee (Apis mellifera L.) colonies are subjected to many persistent viral infections that do not exhibit clinical signs. The identification of criteria that could identify persistent or latent infections in bee colonies is a challenging task for field investigators and beekeepers. With this aim in view, we developed a molecular method to estimate the viral loads for six different RNA viruses in bee and mite individuals collected from seemingly healthy colonies (360 colonies). The data showed very large viral titres in some samples ( $>10^{9}$ copies per bee or mite). Discrepancies between adults and pupae viral RNA loads and, in several instances, significant seasonal variations among viruses were observed. The high titres of some RNA viruses recorded in mites confirm that Varroa destructor could promote viral infections in colonies.
\end{abstract}

\section{Apis mellifera / Varroa destructor / quantitative PCR / viral load}

\section{INTRODUCTION}

More than fifteen viruses have been described from honey bees to date, most of which are $30 \mathrm{~nm}$ isometric particles containing a single positive strand RNA (Bailey and Ball, 1991). The complete genomic sequences from several of these are now available in the public DNA sequence data bases. These include, on one hand, sacbrood virus (SBV) (Ghosh et al., 1999), deformed wing virus (DWV) (Lanzi et al., 2006) and Kakugo virus (KV) (Fujiyuki et al., 2004) assigned to the genus Iflavirus, and, on the other hand, Kashmir bee virus (KBV) (de Miranda et al., 2004), acute bee paralysis virus (ABPV) (Govan et al., 2000) and black queen cell virus (BQCV) (Leat et al.,

Corresponding author: Laurent Gauthier, gauthiel@supagro.inra.fr

* Manuscript editor: Klaus Hartfelder
2000) classified as Cripavirus (family Dicistroviridae). The chronic bee paralysis virus (CBPV) remains unclassified (Ribière et al., 2002). According to epidemiological studies (Tentcheva et al., 2004b; Antunez et al., 2006; Berenyi et al., 2006; Chen et al., 2006), these viruses appear to be prevalent in honey bee colonies, a situation resulting most likely from intensive exchanges of honey bee stocks throughout the world and from the epizooty due to the ectoparasitic mite Varroa destructor Anderson \& Trueman. This hematophagous mite is a potent vector or activator of several bee viruses, both in immature and in adult developmental stages (Bowen-Walker et al., 1999; Martin, 2001; Nordstrom, 2003; Chen et al., 2004; Shen et al., 2005; Tentcheva et al., 2006).

Because viruses are factors which may contribute to colony losses, several identification methods using classical PCR assays have 
been developed (Stoltz et al., 1995; Benjeddou et al., 2001; Grabensteiner et al., 2001; Bakonyi et al., 2002; Ribière et al., 2002; Ongus et al., 2004; Tentcheva et al., 2004a; Genersch, 2005). Among the methods available for quantifying a specific RNA from environmental microbial samples, the application of reverse transcription (RT) in conjunction with real time quantitative PCR allows for the rapid analysis of large number of samples while maintaining a high degree of both sensitivity and specificity (Freeman et al., 1999; Bustin and Nolan, 2004). This method was recently developed for analysing viral RNA loads from individual bees or mites (Chen et al., 2005; Blanchard et al., 2006; Chantawannakul et al., 2006; Tentcheva et al., 2006), as well as in different infected bee organs (Fievet et al., 2006).

However, the evaluation of viral loads from individual bees may not necessarily reflect the situation prevailing at the colony level that must be taken into account when studying social insects. In order to get a better insight into the sanitary status in a given beehive or bee apiary, we have developed a protocol for the quantification of six RNA viruses (DWV, SBV, CBPV, ABPV, BQCV and KBV) at the colony level and we report here the statistical distribution of the viral loads recorded in 360 honey bee colonies in France where these 6 viruses were previously detected (Tentcheva et al., 2004b).

\section{MATERIALS AND METHODS}

\subsection{Bee and Varroa destructor mite sampling}

Bee and mite samples were collected from 360 seemingly healthy bee colonies, as previously described (Tentcheva et al., 2004b). Ten colonies were sampled from each of 36 apiaries. Each colony was carefully checked for the absence of any clinical signs of disease. A $V$. destructor-free apiary (\#429) located on Ouessant Island, Brittany region, was included in this study. The distribution of the 36 apiaries covered the whole French territory. Each bee sample consisted of pools of 100 adult bees or 30 bee pupae collected at three times during 2002: in spring (from March to 15th June), summer (from 16th June to 15th August) and autumn (from 16th August to November). The bee samples were harvested by beekeepers, placed in cardboard boxes and immediately sent to the laboratory by express mail. The adult bee samples were received alive in Montpellier and stored at $-20{ }^{\circ} \mathrm{C}$ before RNA extraction processing. The pupae were removed from their puparia using toothpicks immediately after reception and stored at $-20{ }^{\circ} \mathrm{C}$. Mite samples (a hundred per colony) were collected in the end of $\mathrm{Au}-$ gust or beginning of September, following colony treatment with acaricide.

\subsection{Sample preparation and cDNA synthesis}

The samples were prepared for total RNA extraction as described (Tentcheva et al., 2004b). Adult bees (100 individuals), pupae (30 individuals) and mites (100 individuals) were crushed in a mortar in the presence of liquid nitrogen and homogenised in $20 \mathrm{~mL}, 6 \mathrm{~mL}$ or $0.2 \mathrm{~mL}$ TN buffer (10 mM Tris; 400 mM NaCl; pH 7.5), respectively. After clarification, $50 \mu \mathrm{L}$ of supernatant was collected and used for total RNA extraction using the Nucleospin RNA-II ${ }^{\circledR}$ kit (Macherey-Nagel) following supplier's recommendations. About $10 \mu \mathrm{g}$ of total RNA was purified from each sample and $2 \mu \mathrm{g}$ was retro-transcribed at $25{ }^{\circ} \mathrm{C}$ for $10 \mathrm{~min}$ and at $50{ }^{\circ} \mathrm{C}$ for one hour with the Thermoscript ${ }^{\circledR}$ RT-PCR kit (Invitrogen) using random hexamers. A master mix was used for cDNA synthesis. The cDNA was eventually diluted 10 fold in water and stored at $-20{ }^{\circ} \mathrm{C}$ or processed for PCR assays.

An exogenous internal reference RNA (Johnson et al., 2005) consisting of $5 \times 10^{7}$ copies of Tobacco Mosaic Virus (strain INRA - personal gift of Dr B. Alliot, ENSAM Montpellier) was introduced into each sample during total RNA preparation. The TMV was quantified by spectrometry. This allowed us to monitor the efficiency of RNA purification and cDNA synthesis steps, and to reveal the presence of PCR inhibitors in the samples (Tentcheva et al., 2006).

\subsection{Quantitative PCR assays}

Samples were quantified on an ABI PRISM $7000^{\circledR}$ apparatus (Applied Biosystems) using the SYBR Green I 2X Reaction System ${ }^{\circledR}$ kit (Eurogentec) according to a published protocol $\left(50{ }^{\circ} \mathrm{C}\right.$ 
2 min, $95{ }^{\circ} \mathrm{C} 10$ min and 40 cycles: $95{ }^{\circ} \mathrm{C} 15 \mathrm{~s}$, $60^{\circ} \mathrm{C} 1 \mathrm{~min}$ ) (Tentcheva et al., 2006). For each analysis, $5 \mu \mathrm{L}$ of the diluted cDNA was deposited in duplicates on 96 well PCR plates (Thermo-fast ${ }^{\circledR}$, Abgene) sealed with an optical adhesive cover (Applied Biosystems). The fluorochrome ROX (6 Carboxy-X-Rhodamine, Interchim) was included in the reaction mix at $0.5 \mu \mathrm{M}$ final concentration as a passive reference used to normalise the signal between each 96 wells of the PCR plate. Non-template controls (water) were included in triplicates in each assay. After several trials, the primer concentrations were fixed at $0.2 \mu \mathrm{M}$. The specificity of the amplicons synthesised during the PCR run was ascertained by performing a dissociation curve protocol from $60{ }^{\circ} \mathrm{C}$ to $95^{\circ} \mathrm{C}$.

Viral analysis were not normalized according to their corresponding TMV RNA control values but invalidated if these values were out of the 95\% interval of confidence of the TMV RNA population recorded on the PCR plate. Likewise, duplicates displaying a coefficient of variation greater than $20 \%$ were rejected and analysed again in triplicates.

\subsection{Primers design}

Primers were designed for maximum PCR efficiency from viral genome sequences deposited in GenBank using the Primer Express ${ }^{\circledR}$ software (Applied Biosystems). Primer sequences are presented in Table I. Due to BQCV sequence variations in the RNA dependent RNA polymerase domain, some BQCV positive samples $(n=122)$ were quantified using a pair of primers matching in the BQCV helicase domain (GenBank: AF125252). The corresponding calibration curves were obtained from tenfold dilutions of a BQCV positive cDNA (\#1051IIA05). Primers used for quantification of the exogenous RNA reference (TMV) were described previously (Tentcheva et al., 2006).

\subsection{Calibration curves}

In order to estimate the number of virus genome equivalent copies in the samples, virus specific PCR amplicons were produced using primers described in Table I. These amplicons were generated using standard PCR conditions $\left(95^{\circ} \mathrm{C} 2 \mathrm{~min}\right.$ then $35 \mathrm{cy}$ cles $\left[95^{\circ} \mathrm{C}, 30 \mathrm{~s} ; 56{ }^{\circ} \mathrm{C}, 30 \mathrm{~s} ; 72^{\circ} \mathrm{C}, 1 \mathrm{~min}\right]$ and a 7 min step at $72{ }^{\circ} \mathrm{C}$ to complete the polymerisation).
The length of the amplicons was designed for encompassing the short viral sequence target used in the quantitative PCR assays. These amplicons were gel purified and aliquots were used for measuring their DNA concentration using a fluorescent assay according to manufacturer's procedure (Picogreen ${ }^{\circledR}$ Molecular Probes). For each quantitative PCR assay, ten fold serial dilutions in water were made and each dilution was processed in triplicates on the same 96 well PCR plate where the samples were deposited. The PCR efficiency of each calibration curve was calculated according to the formula: $S=$ $-1 / \log (1+E), S$ and $E$ being the slope and the PCR efficiency, respectively.

\subsection{Statistical analysis}

Statistical analysis were performed using the SigmaStat ${ }^{\circledR} 2.03$ software (Systat). Non parametric tests (Mann-Whitney, ANOVA on ranks) were used.

\section{RESULTS}

\subsection{Design of the protocol}

The protocol was designed for the analysis of pooled samples of 100 adult workers, 30 bee worker pupae and 100 mites per colony, to take into account the viral load variations that may occur among individuals. Furthermore, the sampling was repeated three times in the year 2002 to investigate possible seasonal variations. The optimisation phase of the protocol based on the screening of a large number of cDNA samples showed that quantitative PCR analysis could be performed in duplicates. The divergence reported in some samples between duplicate values was corrected by analysing these samples again in triplicates.

The virus loads were estimated by referring to standard curves established from purified DNA fragments encompassing each virus target sequence used in quantitative PCR assays. These DNA fragments were tenfold diluted and used as templates on each PCR plate for estimating the number of equivalent genome copies in infected samples. For all of the six viruses, the average values of the calculated slope was -3.32 which indicates a PCR efficiency close to 
Table I. List of the primers used for performing quantitative PCR assays or for establishing standard curves.

\begin{tabular}{|c|c|c|c|c|}
\hline \multicolumn{5}{|c|}{ Quantitative PCR primer sequences } \\
\hline$\underline{\text { Virus }}$ & $\underline{\text { Forward primer }}$ & Reverse primer & Fragment length & $\underline{\mathrm{Tm}}$ \\
\hline DWV & GGATGTTATCTCCTGCGTGGAA & CCTCATTAACTGTGTCGTTGATAATTG & 69 & 78.5 \\
\hline SBV & TGTTTAAATTCGGTTCACTTA & GCGCGCCACTAGGTGATC & 70 & 79 \\
\hline CBPV & GATACCGTCGTCACCCTCATG & CGGCAACGGATTCATCAAC & 97 & 84 \\
\hline ABPV & AAATGATACCGGTGGGCAGAT & AAGGTCGTATGTCCGTCTTACCA & 66 & 80 \\
\hline $\mathrm{BQCV}_{(1)}$ & CGACAGCGTGCCAAAGAGA & CGCCCAGCTTTGAAACAGA & 85 & 80.5 \\
\hline $\mathrm{BQCV}_{(2)} *$ & GTACATTTTCTACTGATTGTTACACTTTCGT & CGCAACTACTTCATCTATCAATTCATT & 107 & 77.5 \\
\hline KBV & CGTCGACCTATTGAAAAAGTTAATCA & TGAGAAGTCCATTGGTCCATTTG & 69 & 76 \\
\hline \multicolumn{5}{|c|}{ Primers used for calibration curves } \\
\hline$\underline{\text { Virus }}$ & Forward primer & Reverse primer & Fragment length & $\underline{\text { Ref. }}$ \\
\hline DWV & TTTGCAAGATGCTGTATGTGG & GTCGTGCAGCTCGATAGGAT & 395 & AY224602 \\
\hline SBV & GGATGAAAGGAAATTACCAG & CCACTAGGTGATCCACACT & 426 & AF092924 \\
\hline CBPV & AGTTGTCATGGTTAACAGGATACGAG & TCTAATCTTAGCACGAAAGCCGAG & 455 & AF375659 \\
\hline ABPV & CTCAAGTTATACGTAAAATAGCTGGAATT & AACCAACCTTGCTTCCCTTTA & 646 & AF486072 \\
\hline $\mathrm{BQCV}_{(1)}$ & GTCCAGTGTGATATTGCCAA & TCATTAGAAAGCGCCAGACT & 550 & AF183905 \\
\hline KBV & GATGAACGTCGACCTATTGA & TGTGGGTTGGCTATGAGTCA & 414 & AF027125 \\
\hline
\end{tabular}

* Some BQCV positive samples $(\mathrm{n}=122)$ were quantified using the $\mathrm{BQCV}_{(2)}$ primers matching in the putative BQCV helicase domain $(\mathrm{GenBank}$ : AF125252). Tm: melting temperature of the amplicon. Ref.: GenBank accession number. 


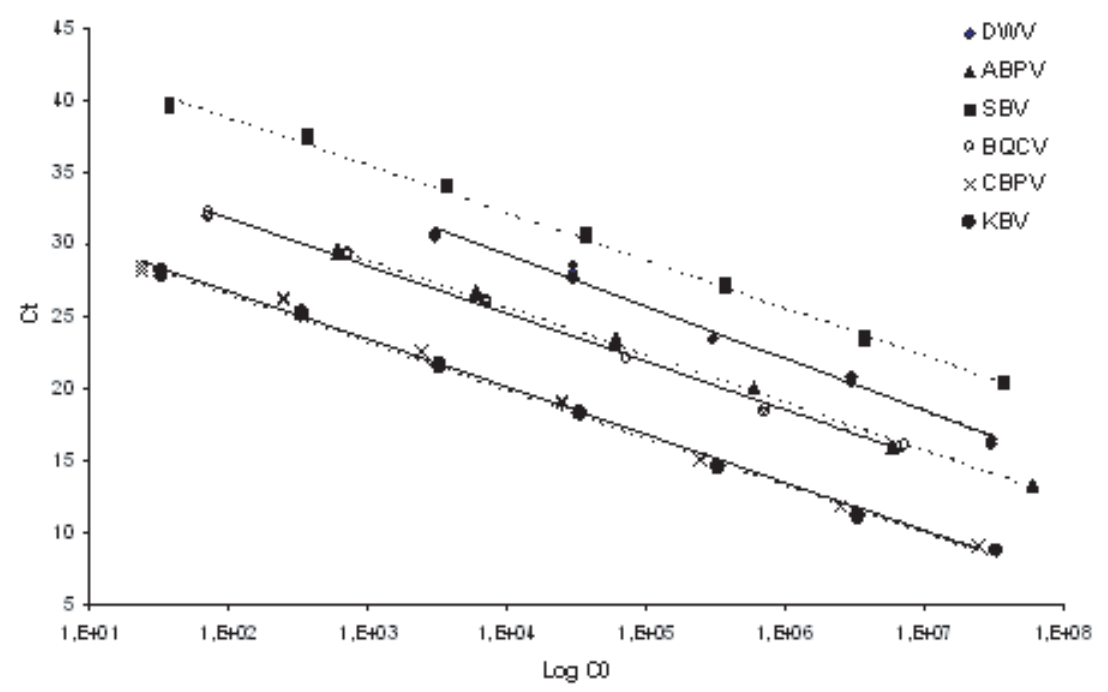

Figure 1. Standard curves used to evaluate the viral loads in infected samples were generated by plotting CT values against the known initial copy number of DNA fragments per $25 \mu \mathrm{L}$ qPCR mixture volume. Dilution series were performed from purified PCR fragments and analysed in triplicates. Log CO: logarithm of the template concentration. CT: cycle threshold value.

100\% (DWV: $-3.325152 ;$ SBV: -3.322876 ; ABPV: -3.320606; CBPV: -3.321830; BQCV: -3.325994; KBV: -3.324527). Standards exhibited linear ranges over 6 to 7 orders of magnitude (Fig. 1). Below 300 DNA standard copies, positive samples were considered detected but not quantifiable. Thus, considering the RNA extraction from 100 workers in $20 \mathrm{~mL}$ buffer or 30 bee pupae homogenised in $6 \mathrm{~mL}$ buffer, the quantification threshold of our assay corresponds to 240000 viral genome equivalent copies per bee $(300 \times 800$ dilution factor). For 100 mites homogenized in $200 \mu \mathrm{L}$ buffer, the quantification threshold was 2400 viral genome equivalent copies per mite $(300 \times 4$ dilution factor $)$.

The primer sequences used in quantitative PCR assays were designed to be as short as possible to maximize the PCR efficiency (Tab. I). Despite this, the quantities recorded in samples were very likely underestimated because of the RNA extraction and reverse transcription steps which are known to operate below 100\% efficiency (Bustin and Nolan, 2004). Moreover, we cannot exclude a difference in the cDNA synthesis efficiency between the different viruses diagnosed. This lat- ter factor might introduce a bias in the analysis of the results. As we previously demonstrated (Tentcheva et al., 2006), the spiking of samples with an exogenous internal reference such as TMV helps to overcome the errors generated by RNA extraction and reverse transcription steps.

\subsection{Quantitative determination of viral genomes in honey bee colonies}

A total of 360 honey bee colonies were screened for the detection and the quantification of DWV, SBV, CBPV, ABPV, BQCV and $\mathrm{KBV}$ in adult workers and in worker pupae using the quantitative PCR technique. The recorded values from each of the 360 honey bee colonies were corrected according to their respective dilution factors (800 for bees and 4 for mites) to present the data in number of equivalent genome copies per bee or mite. These data can be retrieved from the additional file linked to this article. The descriptive statistics of these data are presented in Figure 2.

When pooling viral loads recorded in adult worker samples, two populations could be statistically differentiated using an ANOVA on 

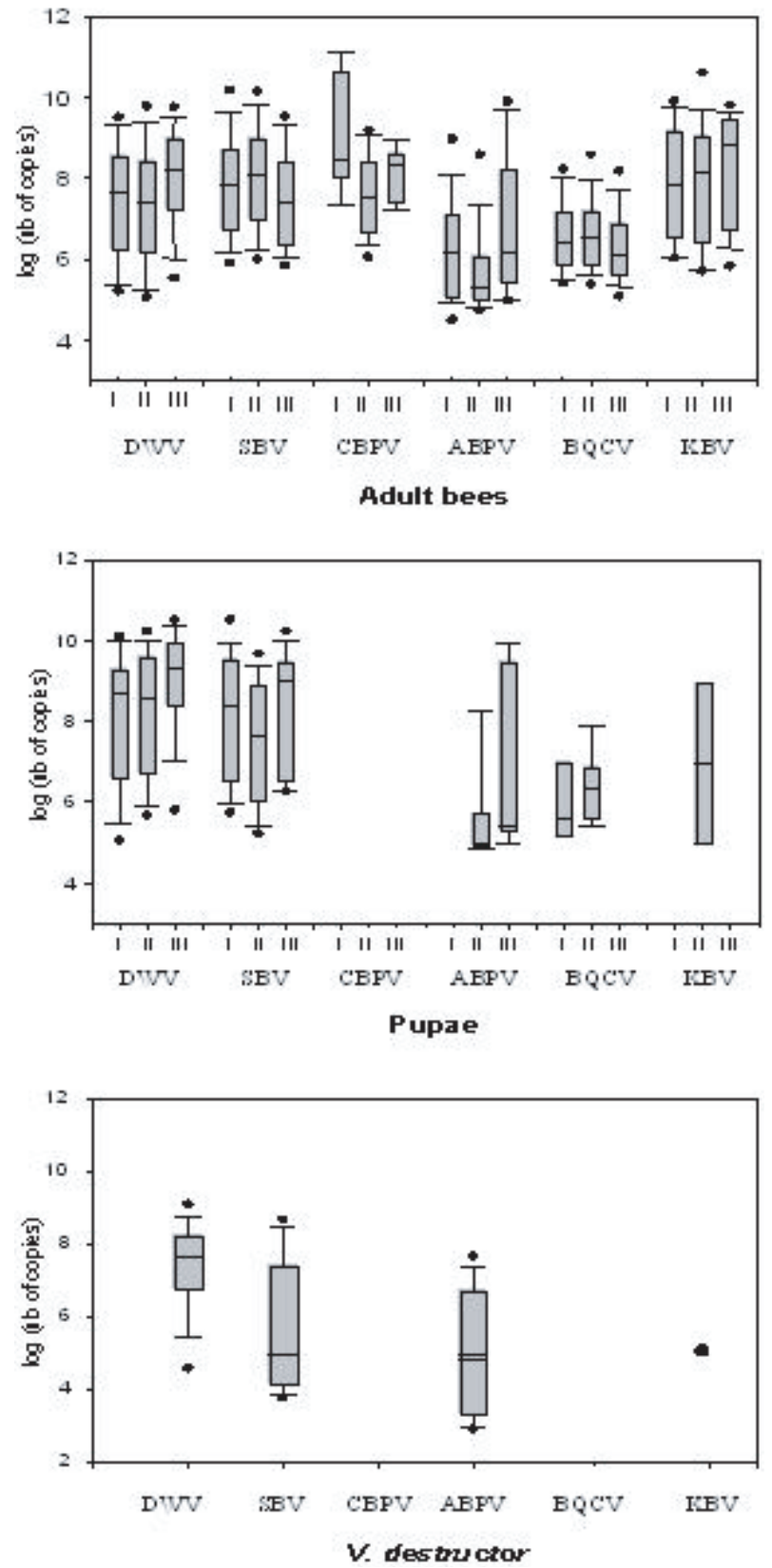

Figure 2. Distribution of viral loads among PCR positive samples collected from honey bee colonies. I, II and III: samples collected in spring, summer and fall, respectively. The values included in the $95 \%$ confidence interval of the population are included between dots. Bars correspond to the 10th and the 90th percentiles. Quartiles are represented in dotted box. The mean is indicated into each box. ranks test $(\mathrm{df}=5 ; \mathrm{H}=347.828 ; P<0.001)$. The first population included the ABPV and BQCV infected samples $\left(\right.$ mean $=1.52 \times 10^{8}$ RNA equivalent copies) and the second included DWV, KBV, SBV and CBPV infected samples $\left(\right.$ mean $=2.14 \times 10^{9}$ RNA equivalent copies).
A Mann-Whitney rank sum test showed that pupae samples had approximately five times more DWV RNA loads than adults ( T = 242.366; $P<0.001)$. Conversely, SBV RNA loads were equally distributed between pupae and adults $(\mathrm{T}=32.793 ; P=0.949)$. The average values were $5.12 \times 10^{9}$ and $1.08 \times 10^{9}$ 
DWV RNA equivalent copies and $3.36 \times 10^{9}$ and $3.19 \times 10^{9} \mathrm{SBV}$ RNA equivalent copies in pupae and adults, respectively. Due to the low number of positives, such statistical analysis could not be performed for ABPV, BQCV and KBV. No positive CBPV pupae were detected from our samples (Tentcheva et al., 2004b).

An ANOVA on ranks test was used to identify seasonal variations of viral loads. No statistical differences among the seasons were observed for the CBPV or KBV adult samples (CBPV infected adults: $\mathrm{df}=2 ; \mathrm{H}=4.443$; $P=0.108 / \mathrm{KBV}$ infected adults: $\mathrm{df}=2$; $\mathrm{H}=0.646$; $P=0.724)$, or for the SBV pupae samples (SBV pupae: $\mathrm{df}=2 ; \mathrm{H}=5.78$; $P=0.056$ ). Owing to the low number of positives, such statistical analysis could not be performed for ABPV and BQCV pupae samples. DWV pupae and adults samples collected in fall had significantly more DWV RNA loads than samples collected in spring and summer (pupae: $\mathrm{df}=2 ; \mathrm{H}=22.56 ; P<0.001$ / adults: df $=2 ; \mathrm{H}=35.82 ; P<0.001)$. Significant variations were also observed in adult bees showing lower ABPV RNA yields in summer (df $=2 ; \mathrm{H}=14.408 ; P<0.001)$ than in spring and fall, while BQCV and SBV RNA yields decreased slightly in fall (BQCV infected adults: $\mathrm{df}=2 ; \mathrm{H}=10.095 ; P=0.006$; SBV infected adults: $\mathrm{df}=2 ; \mathrm{H}=13.15 ; P=$ 0.001).

The analysis showed that $V$. destructor mites had 50 times more DWV RNA loads than ABPV and SBV RNA loads $(\mathrm{df}=2 ; \mathrm{H}$ $=45.94 ; P<0.001)$. The average values were $2.77 \times 10^{7}, 4.97 \times 10^{5}$ and $1.16 \times 10^{5} \mathrm{DWV}, \mathrm{SBV}$ and ABPV equivalent RNA copies per mite, respectively.

\section{DISCUSSION}

Because many viruses and other microorganisms may cause persistent infections in honey bee colonies in the absence of disease symptoms, one can only speculate about the origin of clinical signs observed in field (e.g. colony collapse). The quantitative PCR technique may however provide an opportunity to correlate the viral loads recorded in colonies to a definite pathology by fixing a critical thresh- old sustainable for the colony. To this aim, we developed a quantitative molecular approach and we present here the viral load distribution of six RNA viruses recorded from Apis mellifera L. and $V$. destructor samples collected from 360 seemingly healthy honeybee colonies.

The method involves extrapolating viral copy number (RNA) from curves made from PCR products (DNA). Then, one should take into account that the cDNA synthesis efficiency might vary between different viruses, introducing a possible bias in the data analysis.

The statistical analysis of adult bee samples distinguished two populations regarding the mean number of virus in the samples. These observations might correspond to the different kinetics of viral replication in their host or to different tissue tropisms. For example, different kinetics of viral replication were described for ABPV and KBV, two genetically closely related viruses, using artificial inoculations of bee pupae (Bailey and Ball, 1991). However, the highest RNA loads were recorded in our bee samples for DWV, despite the fact that this virus was found to replicate slowly in the bee using experimental inoculations (Bailey and Ball, 1991). This discrepancy can be explained by the DWV genetic population diversity which could produce variants with an increased virulence against bees. It has recently been proposed that Varroa destructor might influence the genetic outcome of viral populations toward an increased pathogenicity for the bee (Yue and Genersch, 2005).

We showed that bee pupae had higher DWV RNA loads than adults. This supports a previous study from individual bee analysis (Chen et al., 2005) and further suggests that pupae may be more susceptible to DWV replication. The discrepancy between DWV RNA loads in adults and in pupae might result from the fact that diseased adults have much shorter life spans, which will reduce the adult virus titre in the sample. The hygienic behaviour of young bees, which could remove the highly infected pupae, could also contribute to lower virus titres. Another hypothesis would involve the clearing of DWV particles during moulting or their degradation in certain adult bee 
tissues. Likewise, pupae may be more susceptible to virus replication because metamorphosis involves several mechanisms which may reduce the efficacy of the immune defences. Interestingly, this pattern was not observed in SBV infected colonies, where SBV RNA loads were equally distributed between pupae and adults. These data are in agreement with a previous study showing that DWV and SBV seem to display different biological features (Shen et al., 2005).

In mites, the DWV RNA loads were significantly higher than in ABPV or SBV RNA loads. This supports the hypothesis that DWV can replicate in the mite, as has been suggested by previous work showing the PCR amplification of DWV replicative RNA forms in mites (Yue and Genersch, 2005; Ongus et al., 2004).

We found that DWV RNA titres increased during the end of the year, both in adult workers and in pupae populations. This result is in agreement with our previous data showing that the frequency of DWV positive colonies increase from spring to fall (Tentcheva et al., 2004b). This might be correlated with both the higher mite infestation rates in bee colonies during summer and to the higher proportion of DWV infected nurses, which might propagate the virus through the feeding of larvae. Similarly, the slight decrease of BQCV and SBV loads in adults in the last sampling was correlated to their lowest prevalence in fall (Tentcheva et al., 2004b), suggesting that these viruses may not be propagated by the mite which is abundant in the end of the year. We could not find a clear explanation for the decrease of ABPV RNA titres in summer, except that the shorter life span displayed by summer bees may influence the viral replication rates.

In conclusion, our data show (i) that bee viruses display striking biological differences which, for some of them, might be related to the mite infestation of colonies or to the distinct tissue tropism (Fievet et al., 2006) and replication rates of these viruses in their host and (ii) that bee colonies can tolerate very high loads of viruses without displaying external clinical signs. As these values correspond to an average of 100 or 30 individuals per sample, it is likely that some heavily infected workers present in the sample might suffer from patho- logical effects not observed at the colony level. The relationship of a virus with the colony results probably from a complex system of thresholds and balances between the different castes and workers polyethism. Our data strongly support the concept that bee pathology must be investigated distinctly at the individual bee or the colony level. The choice of the sampling method is then critical in such field investigations in which individual analysis performed from a large number of bees collected in several colonies would appear unrealistic, for both technical and financial reasons.

\section{ACKNOWLEDGEMENTS}

We thank French beekeepers who participated to this survey, Dr B.V. Ball for providing viral isolates, Dr P. Neumann for constructive criticism and for improving the manuscript. This work was supported by a grant from the EEC and the French Ministère de l'Agriculture et de la Pêche (Règlement CE $n^{\circ}$ 1221/97, convention $\left.n^{\circ} 2207\right)$.

Estimation de la charge virale dans des colonies d'abeilles domestiques asymptomatiques à l'aide de la technique de RT-PCR quantitative.

Apis mellifera / Varroa destructeur / PCR quantitative / charge virale

Zusammenfassung - Abschätzung der Viruskonzentration in asymptomatischen Honigbienenvölkern mittels quantitativer RT-PCR. Bei den am häufigsten bei Honigbienen diagnostizierten Viren handelt es sich um $30 \mathrm{~nm}$ grosse positive RNA-Partikel, die als Picorna-ähnliche Viren bezeichnet werden. In diese Klasse gehören das Sackbrutvirus (SBV), das VerkrüppelteFlügelvirus (DWV), das Kaschmir-Bienenvirus (KBV), das Akute-Bienenparalysevirus (ABPV), das Schwarze-Königinnenzellenvirus (BQCV) und das Chronische-Bienenparalysevirus (CBPV). Die Genomsequenzen dieser Viren sind jetzt in DNABibliotheken verfügbar, die die Entwicklung auf PCR beruhender molekularer Diagnoseprotokolle erleichtern. In einer früheren Arbeit berichteten wir die Ergebnisse einer Jahresübersichtsstudie zur Prävalenz und zu jahreszeitlichen Schwankungen der Konzentrationen dieser Viren in augenscheinlich gesunden Bienenständen in Frankreich (Tentcheva et al., 2004). Diese Ergebnisse zeigten klar, dass viele persistente Virusinfektionen in 
Bienenvölkern etabliert sein können (92\% der Bienenstände waren positiv für mindestens drei verschiedene Viren), ohne dass klinische Symptome zu sehen sind. Der weltweite intensive Austausch von Völkern und Bienenmaterial und die durch die ektoparasitische Milbe Varroa destructor, einem wichtigen Vektor und Aktivator verschiedener Bienenviren, hervorgerufenen Epizootien sind vermutlich für das verstärkte Auftreten dieser Viren verantwortlich.

Die Ermittlung von Kriterien, die dazu beitragen können, persistente oder latente Infektionen in Bienenvölkern $\mathrm{zu}$ erkennen, stellen deshalb eine Herausforderung für die Feldforschung und für Imker dar. Um einen Einblick in den Gesundheitszustand von Bienenvölkern, sowohl für Einzelvölker als auch Bienenstände zu erhalten, entwickelten wir ein Protokoll, das eine zuverlässige Quantifizierung von sechs RNA-Viren ermöglicht. Diese quantitative PCR Methode kann dazu beitragen, die Viruskonzentrationen in Bienenvölkern mit bestimmten Pathologien zu korrelieren und kritische Schwellenwerte für die Haltung von Völkern festzulegen.

In der vorliegenden Arbeit stellen wir die Ergebnisse einer statistischen Untersuchung zur Verteilung der Viruskonzentrationen in Proben von Bienen und Milben ( $V$. destructor) aus 360 augenscheinlich gesunden Völkern vor. Die Analyse der Proben von adulten Bienen wies zwei Populationen in Bezug auf Viruskonzentrationen auf. Die erste betraf Proben, die einen mittleren Befall mit AB$\mathrm{PV}$ und BQCV in Konzentrationen von 1,52 $\times$ $10^{8}$ RNA-Kopie- $\ddot{q} q u i v a l e n t e n$ pro Biene aufwiesen. Die zweite umfasste Proben, die mit DWV, $\mathrm{KBV}, \mathrm{SBV}$ und CBPV infiziert waren und Viruskonzentrationen von $2,14 \times 10^{9}$ RNA-KopieÄquivalenten pro Biene aufwiesen.

Die höchsten Virus-RNA-Konzentrationen fanden wir in den für DWV positiven Proben, die, im Gegensatz zu SBV positiven Proben, für Puppen höhere Werte aufwiesen als für adulte Bienen. Bei den DWV-Titern konnten wir einen Anstieg zum Jahresende hin feststellen, während die BQCV- und SBV-Konzentationen zum Herbst hin abnahmen. In Milben waren die DWV-Konzentrationen signifikant höher als die für ABPV und SBV, was darauf hinweist, dass das DWV sich vermutlich in Milben repliziert und dass Varroa der Verbreitung dieses Virus in Völkern förderlich sein kann. Zusammenfassend zeigen unsere Daten dass (i) Bienenviren sich in ihrer Biologie stark unterscheiden, dass (ii) Bienenvölker relativ hohe Viruskonzentrationen tolerieren können, ohne dass sie klinische Symptome zeigen, und dass (iii) das Konzept der Bienenpathologie in seinen Untersuchungsansätzen trennen muss zwischen einzelner Biene und Bienenvolk.

\section{Apis mellifera / Varroa destructor / quantitative PCR / Viruskonzentration}

\section{REFERENCES}

Antunez K., D’Alessandro B., Corbella E., Ramallo G., Zunino P. (2006) Honeybee viruses in Uruguay, J. Invertebr. Pathol. 93, 67-70.

Bailey L., Ball B.V. (1991) Honey Bee Pathology, London: Harcourt Brace Jovanovich.

Bakonyi T., Farkas R., Szendroi A., Dobos-Kovacs M., Rusvai M. (2002) Detection of acute bee paralysis virus by RT-PCR in honey bee and Varroa destructor field samples: rapid screening of representative Hungarian apiaries, Apidologie 33, 63-74.

Benjeddou M., Leat N., Allsopp M., Davison S. (2001) Detection of acute bee paralysis virus and black queen cell virus from honeybees by reverse transcriptase PCR, Appl. Environ. Microbiol. 67, 2384-2387.

Berenyi O., Bakonyi T., Derakhshifar I., Koglberger H. Nowotny N. (2006) Occurrence of six honeybee viruses in diseased Austrian apiaries, Appl. Environ. Microbiol. 72, 2414-2420.

Blanchard P., Ribière M., Celle O., Lallemand P., Schurr F., Olivier V., Iscache A.L., Faucon J.P. (2006) Evaluation of a real-time two-step RT-PCR assay for quantitation of Chronic bee paralysis virus (CBPV) genome in experimentally-infected bee tissues and in life stages of a symptomatic colony, J. Virol. Methods 11, 11.

Bowen-Walker P.L., Martin S.J., Gunn A. (1999) The transmission of deformed wing virus between honeybees (Apis mellifera L.) by the ectoparasitic mite Varroa jacobsoni Oud, J. Invertebr. Pathol. 73, 101-106.

Bustin S.A., Nolan T. (2004) Pitfalls of quantitative real-time reverse-transcription polymerase chain reaction, J. Biomol. Tech. 15, 155-166.

Chantawannakul P., Ward L., Boonham N., Brown M. (2006) A scientific note on the detection of honeybee viruses using real-time PCR (TaqMan) in Varroa mites collected from a Thai honeybee (Apis mellifera) apiary, J. Invertebr. Pathol. 91, 69-73.

Chen Y.P., Pettis J.S., Evans J.D., Kramer M., Feldlaufer M.F. (2004) Transmission of Kashmir bee virus by the ectoparasitic mite Varroa destructor, Apidologie 35, 441-448.

Chen Y.P., Higgins J.A., Feldlaufer M.F. (2005) Quantitative real-time reverse transcription-PCR analysis of deformed wing virus infection in the honeybee (Apis mellifera L.), Appl. Environ. Microbiol. 71, 436-441.

Chen Y.P., Pettis J.S., Collins A., Feldlaufer M.F. (2006) Prevalence and transmission of honeybee viruses, Appl. Environ. Microbiol. 72, 606-611.

de Miranda J.R., Drebot M., Tyler S., Shen M., Cameron C.E., Stoltz D.B., Camazine S.M. (2004) Complete nucleotide sequence of Kashmir bee virus and comparison with acute bee paralysis virus, J. Gen. Virol. 85, 2263-2270. 
Fievet J., Tentcheva D., Gauthier L., de Miranda J. R., Cousserans F., Colin M.E., Bergoin M. (2006) Localization of deformed wing virus infection in queen and drone Apis mellifera L., Virol. J. 3, 1-5.

Freeman W.M., Walker S.J., Vrana K.E. (1999) Quantitative RT-PCR: pitfalls and potential, Biotechniques 26, 112-122, 124-125.

Fujiyuki T., Takeuchi H., Ono M., Ohka S., Sasaki T., Nomoto A., Kubo T. (2004) Novel insect picornalike virus identified in the brains of aggressive worker honeybees, J. Virol. 78, 1093-1100.

Genersch E. (2005) Development of a rapid and sensitive RT-PCR method for the detection of deformed wing virus, a pathogen of the honeybee (Apis mellifera), Vet. J. 169, 121-123.

Ghosh R.C., Ball B.V., Willcocks M.M., Carter M.J. (1999) The nucleotide sequence of sacbrood virus of the honey bee: an insect picorna-like virus, J. Gen. Virol. 80, 1541-1549.

Govan V.A., Leat N., Allsopp M., Davison S. (2000) Analysis of the complete genome sequence of acute bee paralysis virus shows that it belongs to the novel group of insect-infecting RNA viruses, Virology 277, 457-463.

Grabensteiner E., Ritter W., Carter M.J., Davison S., Pechhacker H., Kolodziejek J., Boecking O., Derakhshifar I., Moosbeckhofer R., Licek E., Nowotny N. (2001) Sacbrood virus of the honeybee (Apis mellifera): rapid identification and phylogenetic analysis using reverse transcriptionPCR, Clin. Diagn. Lab. Immunol. 8, 93-104.

Johnson D.R., Lee P.K., Holmes V.F., Alvarez-Cohen L. (2005) An internal reference technique for accurately quantifying specific mRNAs by real-time PCR with application to the tceA reductive dehalogenase gene, Appl. Environ. Microbiol. 71, 3866-3871.

Lanzi G., de Miranda J.R., Boniotti M.B., Cameron C.E., Lavazza A., Capucci L., Camazine S.M., Rossi C. (2006) Molecular and biological characterization of deformed wing virus of honeybees (Apis mellifera L.), J. Virol. 80, 4998-5009.

Leat N., Ball B., Govan V., Davison S. (2000) Analysis of the complete genome sequence of black queencell virus, a picorna-like virus of honey bees, J. Gen. Virol. 81, 2111-2119.
Martin S.J. (2001) The role of Varroa and viral pathogens in the collapse of honeybee colonies: a modelling approach, J. Appl. Ecol. 38, 10821093.

Nordstrom S. (2003) Distribution of deformed wing virus within honey bee (Apis mellifera) brood cells infested with the ectoparasitic mite Varroa destructor, Exp. Appl. Acarol. 29, 293-302.

Ongus J.R., Peters D., Bonmatin J.M., Bengsch E., Vlak J.M., Van Oers M.M. (2004) Complete sequence of a picorna-like virus of the genus Iflavirus replicating in the mite Varroa destructor, J. Gen. Virol. 85, 3747-3755.

Ribière M., Triboulot C., Mathieu L., Aurières C., Faucon J.P., Pépin M. (2002) Molecular diagnosis of chronic bee paralysis virus infection, Apidologie 33, 339-351.

Shen M., Yang X., Cox-Foster D., Cui L. (2005) The role of varroa mites in infections of Kashmir bee virus (KBV) and deformed wing virus (DWV) in honey bees, Virology 342, 141-149.

Stoltz D., Shen X.R., Boggis C., Sisson G. (1995) Molecular diagnosis of Kashmir bee virus infection, J. Apic. Res. 34, 153-160.

Tentcheva D., Gauthier L., Jouve S., CanabadyRochelle L., Dainat B., Cousserans F., Colin M.E., Ball B.V., Bergoin M. (2004a) Polymerase Chain Reaction detection of deformed wing virus (DWV) in Apis mellifera and Varroa destructor, Apidologie 35, 431-439.

Tentcheva D., Gauthier L., Zappulla N., Dainat B., Cousserans F., Colin M.E., Bergoin M. (2004b) Prevalence and seasonal variations of six bee viruses in Apis mellifera L. and Varroa destructor mite populations in France, Appl. Environ. Microbiol. 70, 7185-7191.

Tentcheva D., Gauthier L., Bagny L., Fievet J., Dainat B., Cousserans F., Colin M.E., Bergoin M. (2006) Comparative analysis of deformed wing virus (DWV) RNA in Apis mellifera L. and Varroa destructor, Apidologie 37, 41-50.

Yue C., Genersch E. (2005) RT-PCR analysis of Deformed wing virus in honeybees (Apis mellifera) and mites (Varroa destructor), J. Gen. Virol. 86, 3419-3424. 
Online material 
Presentation of the values recorded from the 360 honey bee colonies analysed in this study. Viral load intervals were arbitrarily chosen for presentation and were represented by different colours. The legend is indicated at the bottom of the figure.

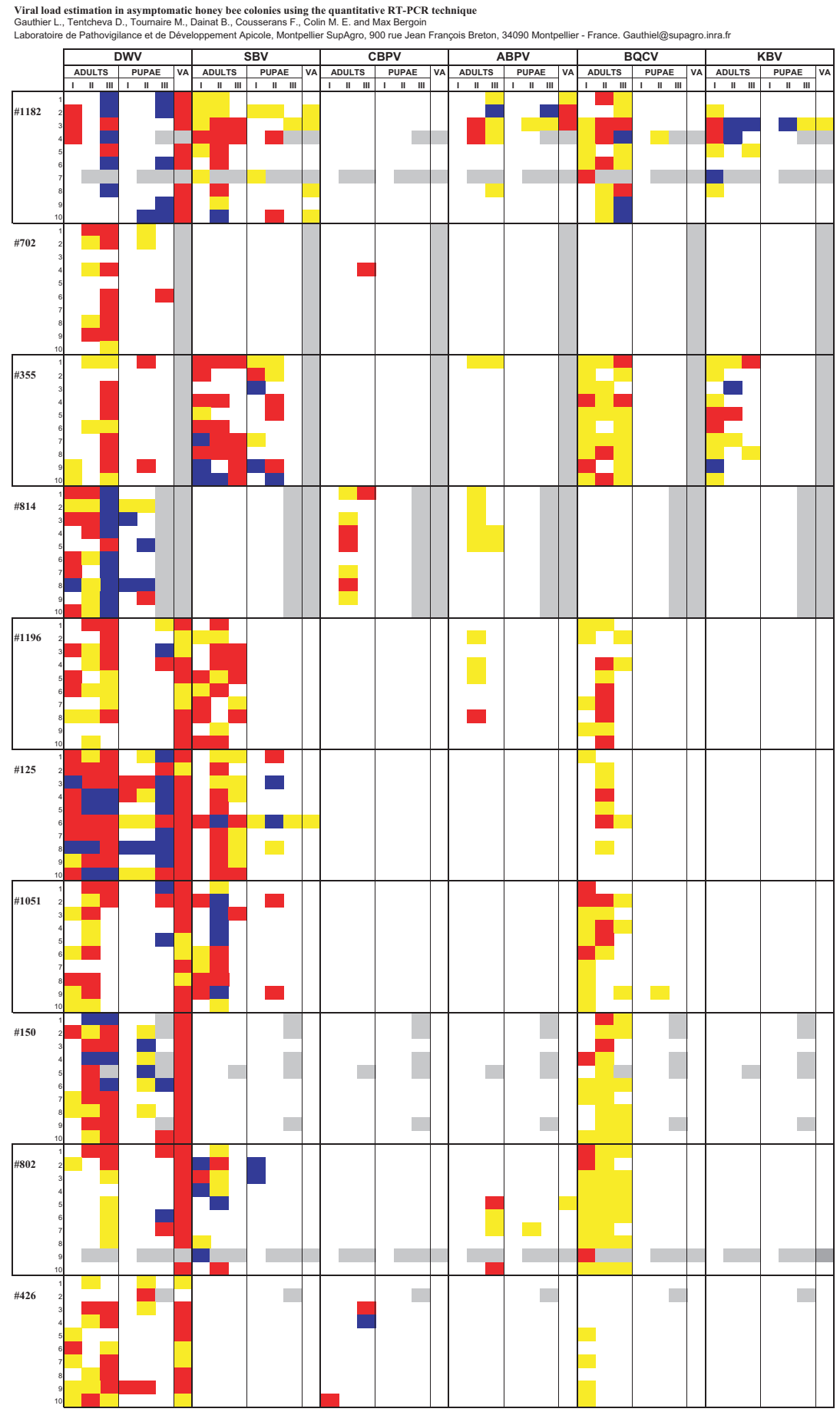




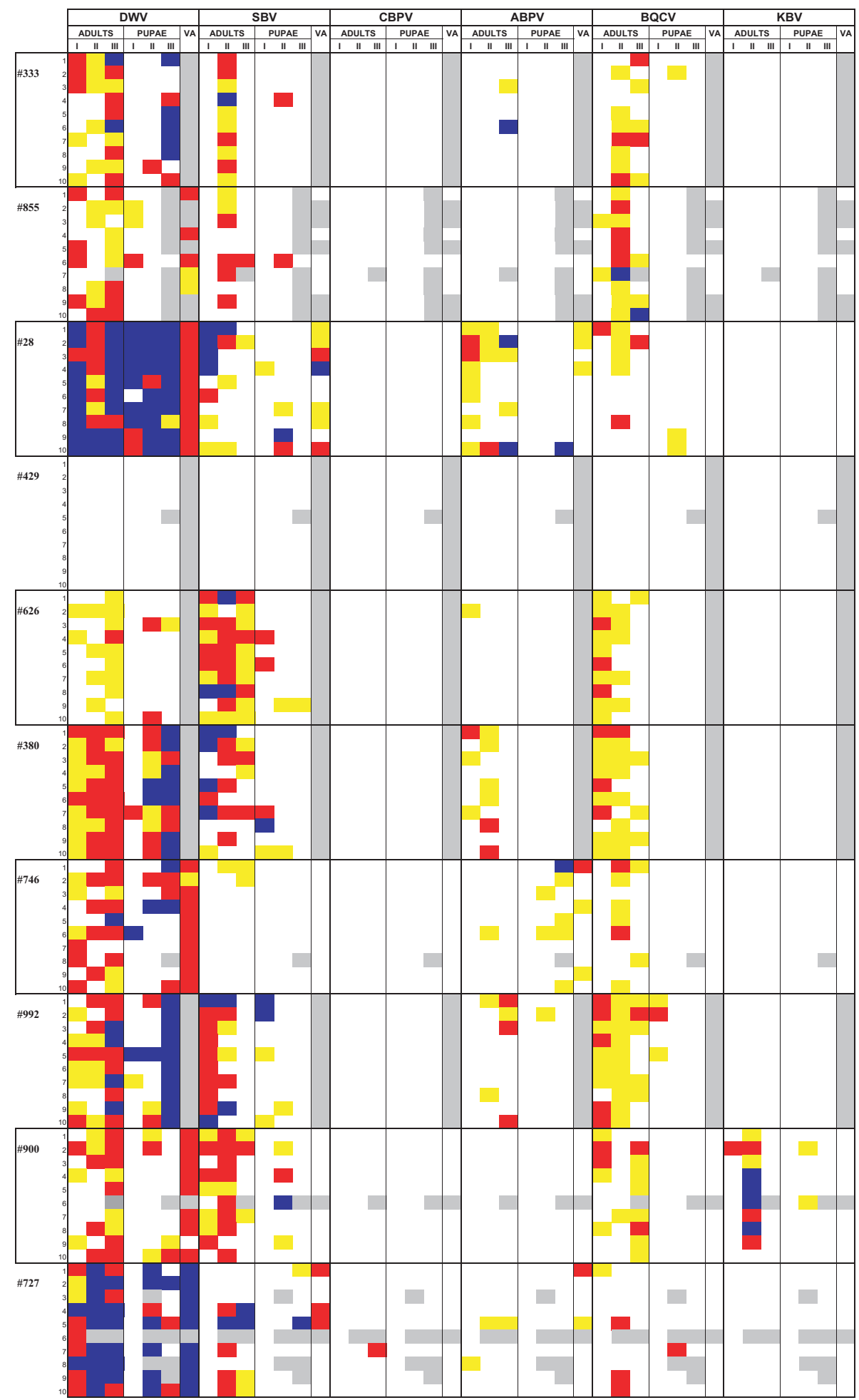




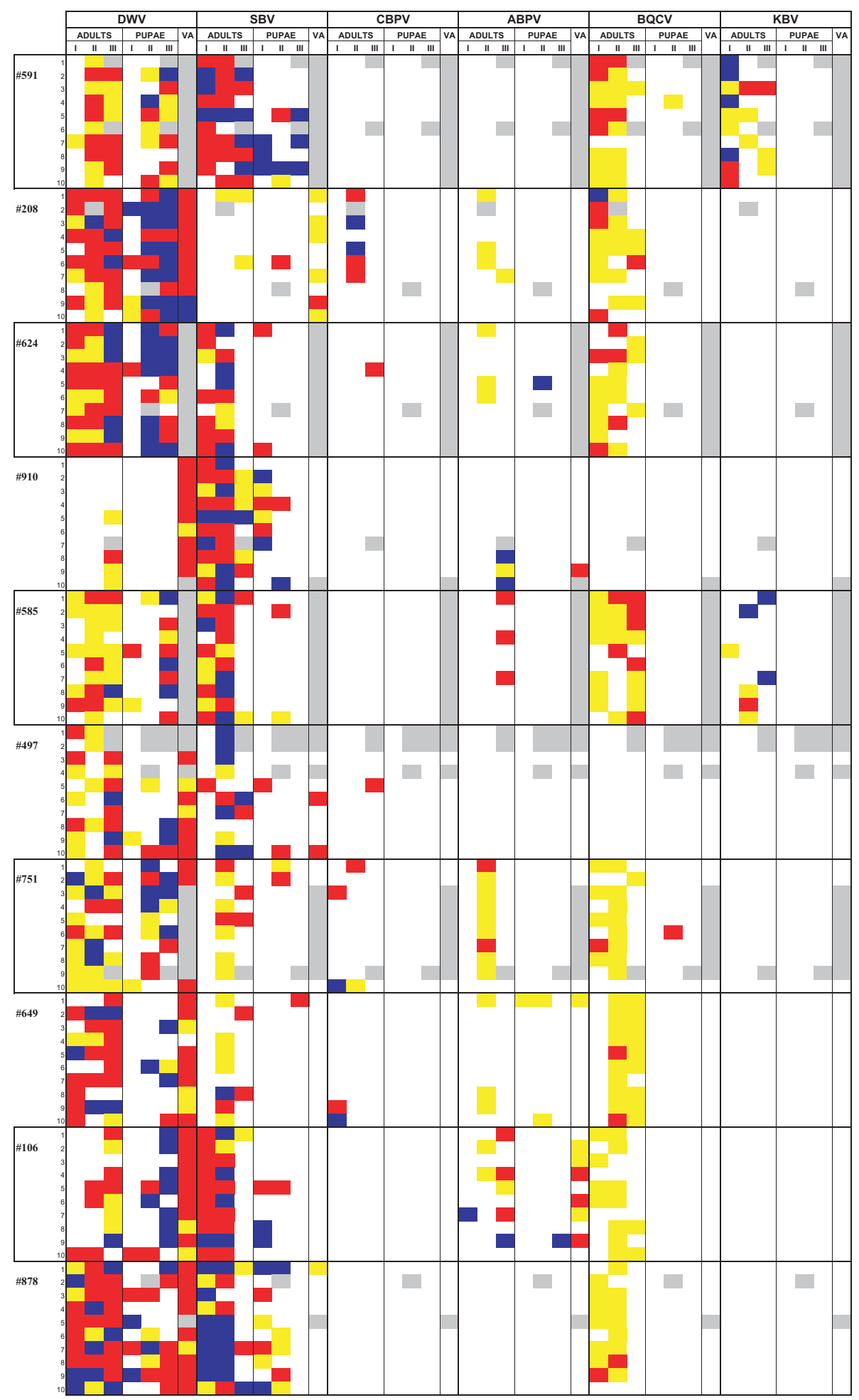




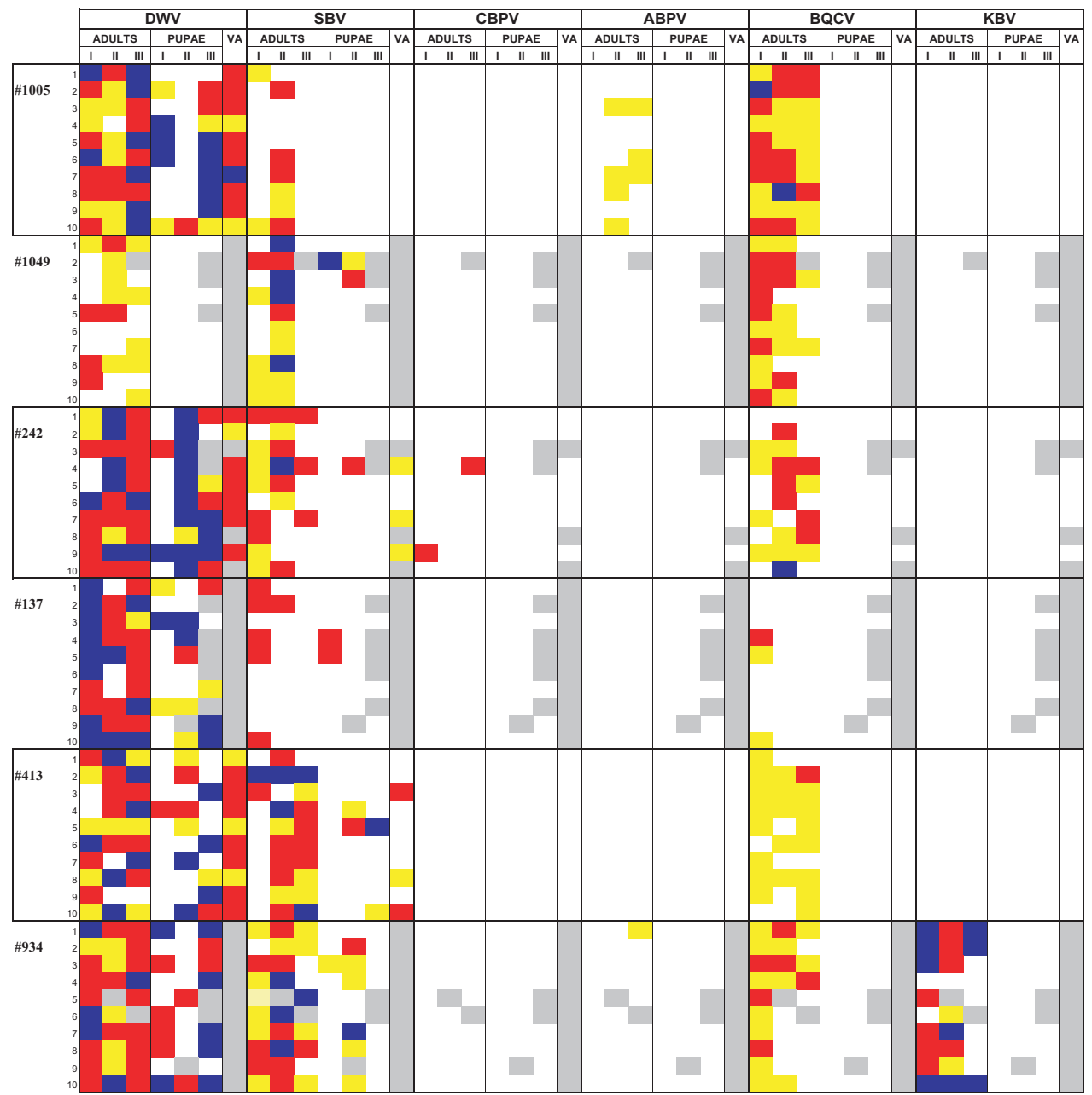

\section{Legend:}

DWV, deformed wing virus SBV, sacbrood virus

CBPV, chronic bee paralysis virus $\mathrm{ABPV}$, acute bee paralysis virus BQCV, Black queen cell virus $\mathrm{KBV}$, Kashmir bee virus

I Samples collected in spring

II samples collected in summer

III samples collected in fall

vA Varroa mites
Sample not analysed

Viral load $>10^{9}$ RNA copies

Viral load between $10^{9}$ and $10^{6}$ RNA copies

Viral load $<10^{6}$ RNA copies

Virus not detected 